\title{
Correspondence
}

\section{The Social Complexity of Southeast Asian Religion: The Current Debate on Buddhism}

Research on Buddhism and society in contemporary South and Southeast Asia has made considerable progress during the past years, and any review of a book published five years ago could be written in the context of the current debate on the structure of Southeast Asian religion. Unfortunately, H. L. Seneviratne did not avail himself of this opportunity in his review (JAS, XXXVI, Feb I977) of my monograph Monks, Priests and Peasants: A Study of Buddbism and Social Structure in Central Ceylon; consequently, he appears to have missed some major issues.

The current debate is summarized by Kirsch in the very same issue of the JAS in which the review appeared. Professor Kirsch starts off his argument with the observation "that Theravada Buddhism is never the sole religious component in these societies, that there are invariably 'non-Buddhist' religious elements present as well, leading H.-D. Evers to suggest that Theravada Buddhism is, in some sense, an incomplete' religion" (p. 242). Much of current research has, at some stage, addressed itself to the question of how Buddhism has found its complementary components, and what religious patterns or systems have emerged. Earlier studies by Ames, Obeyesekere, Tambiah, and others ${ }^{1}$ have postulated a dual structure, in which the "great tradition" of Theravada Buddhism is complemented by a "little tradition" of magical animism. In my study on one of the royal temples of Sri Lanka, this point of view is challenged; and a more complex structure emerges. As Kirsch has come to similar results on the basis of his field data on Thailand and a painstaking analysis of some of the major studies on Burma and Sri Lanka, it is interesting to compare his "model" of religious structure with that put forward in my Monks, Priests and Peasants. Kirsch finds three components in Thai religion: Buddhism, Brahmanism, and animism. The first two are directly comparable to what I have termed the Vihare System and the Devale (temple of gods) System. Kirsch's third component, animism, appears to be different from my third system, the Palace System. The reason for this difference is grounded, I believe, in the different level of analysis adopted in the two studies. Kirsch, as do most anthropologists, argues from the village point of view; I take my clue from a central institution, a royal temple. There is, however, a connecting link. Magical animism is, as well as the Palace System, a system of "power." Religious manipulation of power on a local, peasant level is achieved through magic, on a societal or state level through the charisma of the deva raja, the godking.

${ }^{1}$ M. Ames, "Buddha and the Dancing Goblins: A Theory of Magic and Religion," American Antbropologist, LXVI ( 1964 ), pp. 75-82 and my comment "Magic and Religion in Sinhalese Society," ibid., LXVII ( 1965 ), pp. 97-99; G. Obeyesekere, "The Great Tradition and the Little in the Per- spective of Sinhalese Buddhism," JAS, XXI (1963), pp. 139-54. At that time, I subscribed to the same point of view: "Die soziale Organisation der singhalesischen Religion," Kölner Zeitschrift für Soziologie, XVI ( 1964 ), pp. 314-26. 
My insistence on defining the god-king as the apex of a "religious" system-next to the Buddha as the central figure of the Vihare System-and the gods as the center of the Devale System has recently been challenged on account of a linguistic interpretation of the term deva raja. ${ }^{2}$ Perhaps I have used the term "religious" too loosely; but if we start our analysis from the economic base, the system of land tenure, ownership of wealth, and appropriation of labor (corvée), the three systems are clearly discernible. Considering the economic base without which the functioning of religious systems like Buddhism, Brahmanism, and animism is hardly possible, the terminology of my classification appears to be justified as it refers to three central institutions in Buddhist societies: monastery, temple, and palace (or state)with their appropriate clients and supporters, their administrative staff, their religious specialists, as well as their "superstructure" of ritual and religious ideology.

Kirsch has appropriately characterized studies on Theravada Buddhism as following a historical or a synchronic structural-functional approach. This separation is not without reason. There are considerable methodological problems involved both for the researcher attempting to follow this integrated approach and for the reader of the results, as the misunderstandings in Seneviratne's review indicate. His reference to my analysis of stone inscriptions, chronicles, land grants, colonial records, and other sources as "extensive descriptive material lifted bodily from the tomes of . . civil servants" indicates a lack of understanding of methods of historical research (unless he refers to an appendix, clearly marked as such, in which part of an important I $857-58$ report on temple land tenure has been reprinted). In any case, most of the data derive from a long period of fieldwork, details of which are given in the introduction to the monograph.

Failure to comprehend the importance of a historical dimension leads to another misunderstanding on Seneviratne's part. Toward the end of my analysis, the following problem is put forward:

How is it possible to maintain a social system over a long period of time in which the majority of the population is culturally and religiously undifferentiated while at the same time contrasting religious value systems and their concomitant social organizations are perpetuated? How is it possible to have separate socio-religious structures identifying and dramatizing separate values without splitting and differentiating the members of the society in their allegiance to either system? (p. 99)

Putting the question, as the reviewer does, in an American context and asking "how the American people are one despite the fact that there are two overarching political parties called Democratic and Republican" is, indeed, misleading. The American people are not culturally and religiously "one," nor are the two political parties religious institutions promulgating contrasting religious value systems. It does make sense, however, to consider my question in an Asian context. Indeed, it stands out that the Theravada Buddhist societies of the Sinhalese, Burmese, Lao, Thai, and Khmer are religiously far less differentiated than any of the Indian societies, the Javanese with their Aliran structure, or the Nanyang Chinese whose sectarian differentiation has recently been analyzed by Vivienne Wee. ${ }^{3}$

\footnotetext{
${ }^{2}$ K. R. Norman, Review of Monks, Priests and Peasants in Journal of Modern Asian Studies, X ( 976 ), pp. 466-69.

${ }^{3}$ Vivienne Wee, "'Buddhism' in Singapore" in Riaz Hassan (ed.), Singapore: Society in Transition (Kuala Lumpur: Oxford Univ. Press, r 976), pp. I 55-88. The only "sects" of some importance in modern Theravada Buddhism appear to have been
}

millenarian movements, which, as Charles Keyes has pointed out, were "transitory" phenomena, expressing a "profound social crisis" "Millennialism, Theravada Buddhism, and Thai Society," JAS, XXXVI [1977], p. 302). Neither these movements nor the temporary increase of "Brahmanism" has led to the formation of persistent sects. 
The answer I attempted to provide some ten years ago, when the monograph was written, could, however, be justifiably criticized. Instead of following the thrust of my fieldwork, which started off with an analysis of the economics and politics of the land tenure and service tenure system, I return to a cultural value approach. Contrasting values of the Vihare, Devale, and Palace systems, so goes the argument, are institutionalized in such a way that the outward form and social organization are "parallel" and "supplementary." This, somehow, guarantees the persistence of this triple structure, as the functionally specific services each system provides to society are complementary rather than competitive. It may be argued that this is a functionalstructural reification and ex-post-facto explanation of existing social structures. A much better approach might have been an analysis of these religious systems in the context of the social and economic history of Sri Lanka. The dissolution of the classical Sinhalese state and the trend toward feudalization would have explained the attempts by the Sinhalese radala aristocracy to wrest control over the peasantry from the court. "Tax-free" temple estates, both Vihare (Buddhist) and Devala (gods) estates, provided an opportunity to enhance the power position of the aristocracy. It appears that only within this macro-sociological context will we be able to provide a more satisfying explanation of religious structure in Sri Lanka and, with the appropriate modification, in other Southeast Asian countries.

\section{Universität Bielefeld}

HANS-DIETER EvERS

\section{Han Festivals}

Professor Jack L. Dull, in his review (JAS, XXXVI, Nov I976, pp. I 24-26) of my Festivals in Classical China, says that he found the book difficult to read and review. I regret this fact, but in particular I regret the reviewer's indifference to what seems to me a basic canon of reviewing: the obligation to acquaint the reader with what a book under review actually contains. Aside from a single derogatory reference to "competitive hunting," Dull tells the reader nothing concerning what festivals the book in fact discusses. His initial sentence, in my opinion, is unjust and misleading when it states that "the core of this volume is basically a copiously annotated, partial translation of the 'Treatise on Rituals' of the Hou-Han-shu." For example, the longest single item in the "Treatise" appears in translation in the book's fourth chapter ("The Great Exorcism"), where it covers one and one-half pages as against the sixty-four pages of the chapter as a whole (all of it dealing with the same subject). The "Treatise's" shortest item is translated in the book's tenth chapter ("The Supreme Intermediary"), two sentences (twenty-five English words), as against the eighteen pages of the chapter as a whole. Similar disproportions between translations of the "Treatise" and what Dull would call "copious annotation" characterize the other chapters. The real way in which I used the "Treatise" for writing the book is clearly stated on page I I.

The review criticizes the book for inadequately exploring Han popular beliefs and values, and suggests that these might have been better found by examining the religious background to the rise of the Buddhist and Taoist churches. Even if this suggestion were valid, it would be totally irrelevant to the book under review, 